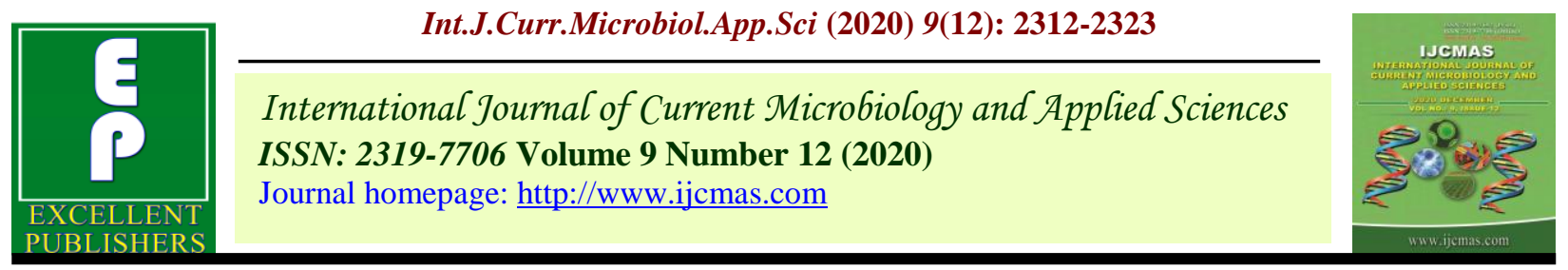

Original Research Article

https://doi.org/10.20546/ijcmas.2020.912.274

\title{
Effect of Phosphorus, Zinc and Iron Levels on Growth and Yield of Kharif Maize (Zea mays L.)
}

\author{
Manoj Pal Thakur*, Joy Dawson and Tarun Thakur \\ Department of Agronomy, Naini Agricultural Institute, SHUATS, Prayagraj, Uttar Pradesh, \\ India \\ *Corresponding author
}

A B S T R A C T

\begin{tabular}{|l|}
\hline K e y w o r d s \\
Kharif maize, \\
$\begin{array}{l}\text { Phosphorous, Zinc, } \\
\text { Iron, growth, yield } \\
\text { and economics }\end{array}$ \\
\hline Article Info \\
\hline $\begin{array}{l}\text { Accepted: } \\
16 \text { November } 2020 \\
\text { Available Online: } \\
\text { 10 December } 2020\end{array}$ \\
\hline
\end{tabular}

A Field experiment was conducted during kharif season 2019-2020 at Crop Research Farm Department of Agronomy, SHUATS, Prayagraj, UP. To study the "Effect of Phosphorous, Zinc and Iron levels on growth and yield of kharif maize (Zea mays L.)". The experiment was laid out in Randomized block design with three replication and 9 treatments out of these application of Phosphorous $60 \mathrm{~kg} / \mathrm{ha}+$ zinc $25 \mathrm{~kg} / \mathrm{ha}+\mathrm{Fe} 25 \mathrm{~kg} / \mathrm{ha}$ in treatment 9 given maximum plant height $(199.03 \mathrm{~cm})$, No. of leaves $(12.73)$, Plant dry weight $(176.23$ g), No. of cob/plant (1.84), Cob length $(20.14 \mathrm{~cm})$, No. of Grain row/cob (17.10), No. of grain/row (24.13), No. of grain/cob (412.73), Test weight (318.0g), Grain yield (2.77t/ha), Straw yield (5.23 t/ha), Harvest index (34.66\%) and the same trend is follow on economic of the experiment i.e. the treatment 9 recorded maximum Gross return of Rs. 88330/ha, Net return Rs. 38632/ha and B:C 1.78. However, the treatment 8 (P $60 \mathrm{~kg} / \mathrm{ha}+$ zinc 25 $\mathrm{kg} / \mathrm{ha}+\mathrm{Fe} 20 \mathrm{~kg} / \mathrm{ha})$ have the maximum CGR (14.56 g/m2 /day) and RGR (0.010 $\mathrm{g} / \mathrm{g} /$ day).

\section{Introduction}

Maize (Zea mays L.) is the most important food crop after rice and wheat. It is a versatile emerging crop having wider adaptability to various Agro-climatic conditions. Globally maize occupies an area of $174.2 \mathrm{~m}$ ha with a production of $852 \mathrm{~m} \mathrm{t}$ and productivity of $4890 \mathrm{~kg} / \mathrm{ha}$. In India, it occupies an area of $9.42 \mathrm{~m}$ ha with a production of $22.26 \mathrm{~m} \mathrm{t}$ and an average productivity of $2583 \mathrm{~kg} / \mathrm{ha}$. In Karnataka, maize occupies an area of $1.38 \mathrm{~m}$ ha, with a production of $4.00 \mathrm{~m} \mathrm{t}$ and average productivity of $2883 \mathrm{~kg} / \mathrm{ha}$. In India, maize is cultivated in the states of Andhra Pradesh,
Karnataka, Bihar, Rajasthan, Madhya Pradesh, Gujarat, Chhattisgarh, Maharashtra, Tamil Nadu and Uttar Pradesh (Anon., 2014). In addition to high demand for macronutrients, micronutrients are required in relatively very small quantities for adequate plant growth and production, micronutrient deficiency may cause great disturbance in the physiological and metabolic processes involved in the plant. The application of micronutrient fertilizers as basal dose may not be reaching the crop requirement for root growth and nutrient use. The alternative approach is to apply these micronutrients through foliar sprays. Foliar application is the 
spraying of fertilizer solutions containing one or more nutrients on the foliage of growing plants. Several nutrient elements are readily absorbed by leaves when they are dissolved in water and sprayed on them. It is effective for the application of minor nutrients like iron, copper, boron, zinc and manganese. There are mainly three advantages of foliar application of fertilizers over soil application, utilization of applied quantity; about more than $90 \%$ fertilizer utilized by the plant when applied in foliar form, translocation within the plant. The Importance of Iron and Zinc Micronutrients are required in low quantities in a balanced human diet (GarcíaBañuelos et al., 2014). They have a significant role in human physiological activities and metabolism (Goudia and Hash, 2015). In humans, $\mathrm{Fe}$ is found in red blood cells as a part of haemoglobin and is essential for $\mathrm{O} 2$ transport from lungs to tissues. As a part of cytochromes, it is essential for oxidative metabolism. Iron not immediately required by the body is stored in the liver as ferritin and hemosiderin (Abbaspour et al., 2014). It 2 differs from other minerals because its balance in humans (except for women of reproductive age) occurs through absorption only, and there is no physical system for its excretion (Hurrell and Egli, 2010). Iron is the most important micronutrient, as it, being the main component of haemoglobin, myoglobin, and cytochromes, is involved in several metabolic reactions, such as energy production, immune defence, and thyroid function (Frossard et al., 2000). It is the main component of various hemi and nonheme $\mathrm{Fe}$ enzymes and carriers, such as cytochromes and ferredoxins. Cytochromes are respiratory electron carriers, whereas ferredoxins are involved in $\mathrm{N}$ fixation, photosynthesis, and electron transfer (Frossard et al., 2000; Fageria et al., 2012). The other important functions of enzymes that contain $\mathrm{Fe}$ are the formation of bile acids and steroid hormones in the liver and controlling of signals in some neurotransmitters, such as serotonin and dopamine systems in the brain (Kumar et al., 2015) In humans, $\mathrm{Zn}$ is mostly present in bones and skeletal muscles. It is responsible for the efficient functioning of >300 enzymes and acts as a stabilizer and protects membrane structure and cell components (Babu et al., 2013; Kumar et al., 2015). Biochemically, it is an important part of $\mathrm{Zn}$-dependent enzymes and plays a significant role in synthesis and degradation of lipids, proteins, nucleic acid, and carbohydrates. It has structural and functional roles in various enzymatic mechanisms that are involved in gene expression (Frossard et al., 2000; White and Broadley, 2009), cell division and growth, immune response, and reproductive functions (Cakmak, 2008; Thakur et al., 2015). Zinc is a major component of many dehydrogenases, proteinases, and peptidases (e.g., carbonic anhydrase and alcohol dehydrogenase) (Fageria et al., 2012). Principal cereals, tubers, legumes, and starchy roots are chief sources of $\mathrm{Zn}$ in low-income populations. However, $\mathrm{Zn}$ from these sources either is low in quantity or has low bioavailability. Cereals, such as maize, provide $50 \%$ of the $\mathrm{Fe}$ absorbed from foods consumed by poor people. Therefore, by increasing $\mathrm{Fe}$ and $\mathrm{Zn}$ contents of food crops, total uptake may be enhanced significantly (Kumar et al., 2015). About $95 \%$ of the foliar fed nutrient solution can be found in the smallest root within 60 minutes, if conditions are optimum and foliar fertilizer use efficiency in sandy loam soils is up to 20 times more effective when compared to soil applied fertilizers. The availability of macro and micronutrients added to the soil will be affected by soil environmental factors. Foliar application technique is a particular way to supply macro and micro-nutrients which avoids these factors and results in rapid absorption. 3 Numerous studies confirmed positive response for the foliar application with the complete foliar fertilization in wheat (Ahmed and Ahmed, 2005). Hence, an 
attempt was made to know the effect of foliar application of micronutrients on growth, yield and nutrient uptake of maize. Crops grown in arid or semi-arid regions are mostly exposed to low soil fertility and exhibit multiple nutrient deficiencies due to low organic matter and alkaline calcareous nature that limit the crop production (Rafique et al., 2006). The prime reason of this deficiency is the unavailability of irrigation water to apply the Most research on soil and foliar application of zinc focused on alleviating its deficiencies, particularly on wheat and rice cultivated in semiarid or arid regions of the world (Alloway, 2004; Cakmak, 2008). Maize was recognized by farmers for a long time as a crop of high response to zinc supply. In temperate regions, due much shorter vegetation and low temperatures prevailing at early stages, maize growth appears to be highly sensitive to many external and internal stresses, which in turn induce grain yield reduction (Leach and Hameleers, 2001; Subedi and Ma, 2009). It was recently documented that zinc foliar application is a simple way for making quick correction of plant nutritional status, as reported for wheat (Erenoglu et al., 2002) and maize (Grzebisz et al., 2008). Based on recent investigations related to factors limiting maize yielding physiology as well as grain yield, a hypothesis was formulated that the external supply of zinc boosts processes responsible for the yielding potential of maize nutrients to crop plants under field conditions in rainfed regions. Secondly, most of the Pakistani farmers do not apply micronutrient especially $\mathrm{Zn}$ and B (Kanwal et al., 2010) that lead to their deficiency in soil and causes yield reduction. Micronutrient deficiencies attributable to malnutrition have irreversible and long-term negative effects on human health (Vasconcelos et al., 2017). Two-thirds of all mortality among children younger than 5 years is attributable to micronutrient deficiencies (Welch and Graham, 2004). The
World Health Assembly is aiming to reduce the number of stunted children due to malnutrition by $40 \%$ in 2025 . It was suggested that mainstreaming nutrition in agricultural programs in regions like SSA would be the best strategy to eliminate malnutrition (Swaminathan, 2012). Many populations, particularly in low-income countries, are deficient in $\mathrm{Zn}, \mathrm{Fe}, \mathrm{I}, \mathrm{Se}$, and Co (Welch, 2008). More than two billion people around the world are victims of hidden hunger (Garg et al., 2018), including Fe and $\mathrm{Zn}$ deficiency, particularly in developing countries (Welch and Graham, 2004; Goudia and Hash, 2015). Deficiencies of $\mathrm{Zn}$ and $\mathrm{Fe}$ rank fifth and sixth among the top 10 most important risk factors responsible for illnesses and diseases in developing countries (Fageria et al., 2012). Iron is critical for human health because its deficiency can be life threatening. It is the most common mineral deficiency in the world (Ghandilyan et al., 2006; Chakraborti et al., 2011). Iron deficiency is widespread in developing countries because of lack of consumption of animal products (which can enhance nonheme Fe absorption and provide highly bioavailable heme $\mathrm{Fe}$ ) and reliance on cereals and legumes as basic staple foods. Such foods are deficient in bioavailable $\mathrm{Fe}$ because of the presence of phytic acid and some polyphenols (Bouis 2002; Tako et al., 2016). Anaemia caused by Fe deficiency affects 800 million women and children in the world (WHO, 2015). The chance of developing Fe deficiency is $40 \%$ in preschool children, $30 \%$ in menstruating girls and women, and 38\% in pregnant women (Pasricha et al., 2013). Maternal and perinatal death and loss of cognitive skills, growth, reproduction, and physical activity, mental retardation, weak immune system, and low work capacity are major threats of $\mathrm{Fe}$ deficiency. Iron deficiency effects have recently been effectively separated on the basis of age, sex, race, socioeconomic rank, and regional differences (Gibson, 2007;). 
Currently, biomarkers such as serum ferritin, transferrin saturation, free red blood cell protoporphyrin, and Creative protein are used to evaluate the occurrence of Fe deficiency. Zinc deficiency is a vital threat to world agriculture and human health, particularly in arid and semiarid zones of the globe. Zinc deficiency affects $17 \%$ of the world's population, which is about two billion people. It causes reduced growth and development, depression, digestive system problems, anorexia, and changed reproductive biology signal transduction, gene expression, apoptosis, cell development, and cell replication (Ortiz-Monasterio et al., 2007). Approximately 800,000 child deaths throughout the world per year are caused by Zn deficiency (Ortiz-Monasterio et al., 2007). The chance of growth inhibition of children under $5 \mathrm{yr}$, attributable to $\mathrm{Zn}$ deficiency, is $29 \%$ in South Asia and 25\% in SSA (Harvest Plus, http://www.harvestplus.org/node/634). Zinc deficiency affects people of all ages, but new born babies, young children, and pregnant and lactating women are more frequently affected. It has a lethal effect on human health that varies with age for example, diarrhoea, skin inflammation, and neurobehavioral complaints are common in babies (Dassoni et al., 2014), whereas young children have skin changes, reduced taste perception, growth delay, and recurring infections. Elderly people are also at risk of $\mathrm{Zn}$ deficiency because of a reduced ability to absorb $\mathrm{Zn}$ in old 5 age. In the United States, $30 \%$ of elderly people are $\mathrm{Zn}$ deficient, which contributes to prolonged nonhealing leg ulcers and recurring infections (Brown et al., 2004; Gibson, 2012). Modern approaches to overcome $\mathrm{Zn}$ deficiency include supplementation, fortification, food diversification, and biofortification. Zinc supplementation is suitable for treatment of severe diarrhoea, and to avert inhibited growth, diarrhoea, pneumonia, and death in children that are severely affected. Zinc- fortified food, such as muesli, is recommended for urban families, whereas food diversification and biofortification are appropriate for rural families (Gibson, 2012; García-Bañuelos et al., 2014)

Considering the above facts, the present study aimed to investigate the effect of Phosphorous, Zinc and Iron levels, with the hypothesis that whether they can enhance the yield and net return of kharif maize crop. Therefore, the objectives are to find out the effect of different level of phosphorous zinc and iron on growth and yield attributes of maize crop and to find out the economics of different treatments.

\section{Materials and Methods}

The experiment was conducted during the kharif season of 2019 at the Crop Research Farm, Department of Agronomy, Sam Higginbottom University of Agriculture, Technology and Sciences (SHUATS), Prayagraj. The Crop Research Farm is situated at $250 \quad 57^{\circ} \mathrm{N}$ latitude, $870 \quad 19^{\circ} \mathrm{E}$ longitude and at an altitude of $98 \mathrm{~m}$ above mean sea level. This area is situated on the right side of the river Yamuna and by the opposite side of Prayagraj City. Prayagraj has a subtropical and semi-arid climatic condition, with both extremes of temperature, i.e. winter and summer. The soil of the experimental field constituting a part of central Gangetic alluvium is neutral and deep. Pre-sowing soil samples were taken from a depth of $15 \mathrm{~cm}$ with the help of an auger. The composite samples were used for the chemical and mechanical analysis. The soil was sandy loam in texture, low in organic carbon $(0.28 \%)$ and medium in available nitrogen (225 kg/ha), phosphorus (19.50 $\mathrm{kg} / \mathrm{ha})$ and low in potassium $(92.00 \mathrm{~kg} / \mathrm{ha})$.

The experiment was laid out in Randomized Block Design (RBD) and replicated thrice. 
There were 9 treatments, comprised of three factors, Factor 1: Levels of Phosphorous application as foliar at $1.45 \mathrm{~kg} / \mathrm{ha}$ and 2.60 $\mathrm{kg} / \mathrm{ha}$, Factor 2: Levels of Zinc application as foliar at $1.20 \mathrm{~kg} / \mathrm{ha}$ and $2.25 \mathrm{~kg} / \mathrm{ha}$, Factor 3 : Levels of Iron application as foliar at 1. 20 $\mathrm{kg} / \mathrm{ha}$ and 2. $25 \mathrm{~kg} / \mathrm{ha}$. Allocation of the treatment was done by the randomization following Fisher and Yates random number table. Multicolour maize variety was used in the experiment. The data were recorded on 5 randomly selected plants from each plot for growth, yield and yield attributes. The growth attributes studied were plant height $(\mathrm{cm})$, number of leaves/plant, plant dry weight (g/plant), crop growth rate (g/m2/day), relative growth rate $(\mathrm{g} / \mathrm{g} / \mathrm{day})$.Yield attribute studied were no. of cob/plant, cob length $(\mathrm{cm})$, no. of row/cob, no. of grain/row, no. of grain/cob, test weight $(\mathrm{g})$, grain yield ( $\mathrm{t} / \mathrm{ha})$, stover yield $(\mathrm{t} / \mathrm{ha})$, harvest index $(\%)$. Along with growth, yield and yield attribute, economics of rice was also studied, which include gross return ( $₹ / h a)$, net return ( $₹ / h a)$, and benefit cost ratio to find out which treatment is more economical to farmers.

The experimental field was thoroughly ploughed and harrowed and brought to fine tilth. Stubbles and weeds were picked up from the field and the land was levelled with the help of rake and the plots were demarcated according to layout. The dose of soil application $\mathrm{N}, \mathrm{P}_{2} \mathrm{O}_{5}, \mathrm{~K}_{2} \mathrm{O}$ along with basal application of $\mathrm{ZnSO}_{4}$ and $\mathrm{FeSO}_{4}$ for maize was worked out according to the present recommendation of maize hybrids in Prayagraj District. The $100 \%$ NPK dose in $\mathrm{kg} / \mathrm{ha}$ worked out was 120:60:60 for maize crop. The doses for phosphorous, zinc and iron were farmed by applying $\mathrm{ZnSO}_{4}$ at $0.5 \%$ $+1.0 \%, \mathrm{FeS}_{4}$ at $0.5 \%+1.0 \%$ and foliar spray of soluble boron at $0.5 \%+1.0 \%$ respectively. Fertilizer application was made as per the treatments, full dose of phosphorus, potash and half dose of nitrogen were applied at sowing as basal application, the remaining dose of nitrogen was top dressed at 30 DAS and 60 DAS depending upon the occurrence of rains. Foliar spray of zinc, iron and boron were mixed with water and applied at 30DAS and 60DAS. The average height of plants was recorded at an interval of 20 DAS, the height of plant was measured from the base of the plant up to the highest point of the arch of the uppermost leaf whose tip is pointing down. Number of green leaves/plants was also recorded at regular intervals of $20,40,60,80$ and 100 DAS from the tagged plants of each plot. Dry weight of plants were recorded with roots by uprooting three plants randomly from each plot, these plants were first air dried then wrapped with paper and then kept in oven for oven drying at $70^{\circ} \mathrm{C}$ for $24-48$ hours, the dry weight of samples were recorded, averaged and expressed as g/plant, For calculating number of cobs/plant, cobs of tagged plants were counted, the average value for each treatment was calculated thereafter. The total number of seed rows/cob from the five fresh cobs was counted and the average was expressed as number of seed rows/cob. Length of the individual cob from selected five plants was measured from the base to the tip of the cob and expressed in centimetres $(\mathrm{cm})$. Five dried cobs were selected at random from the selected plants and their weight was taken. The average was worked out and expressed as weight of cob/plant (g). Number of grains/cobs was counted from cob of five selected plants. Cob of harvested plants of net plot area after proper sun drying were separated from plants, de-husked and shelled with the help of cob sheller. The produce was cleaned, weighed and expressed in terms of grain $\mathrm{kg} / \mathrm{ha}$. Stover yield was obtained by subtracting the grain yield/plot from the respective biological yield/plot and finally expressed in terms of stover yield $\mathrm{kg} / \mathrm{ha}$. Cost of cultivation, gross return, net return and Benefit Cost Ratio were worked out to evaluate the economics of each treatment, 
based on the existing market prices of inputs and output. Benefit: cost ratio was calculated by dividing the net returns from total cost of cultivation. The benefit cost ratio was calculated by using following expression: Net returns ( $₹ /$ ha) $\div$ Cost of cultivation ( $₹ / h a$ ). The data obtained from this study were analysed statistically using the F-test, as per the procedure given by Gomez and Gomez (1984) and 5\% level of significance was used to compared the differences among the treatment. The treatment differences that were non-significant at five per cent were denoted as NS.

\section{Results and Discussion}

\section{Growth attributes}

At 100 DAS significant and maximum plants hight $(199.03 \mathrm{~cm})$ respectively was observed in treatment $9(\mathrm{P} 60 \mathrm{~kg} / \mathrm{ha}+$ zinc $25 \mathrm{~kg} / \mathrm{ha}+$ Fe $25 \mathrm{~kg} / \mathrm{ha}$ ), however except treatments 1,2 and 5 all are found to be at par with this. Improvement in plant height with higher phosphorus levels over and above $40 \mathrm{~kg}$ P2O5 ha-1 (P2) might be attributed to the fact that phosphorus is a constituent of nucleic acids, phospholipids, coenzymes and most importantly ATP. It activates coenzymes for amino acid production used in protein synthesis which might have resulted in better plant height. Similar results were obtained by Gemechu (2011) and Reddy et al., (2018)

At 100 DAS the significant and maximum No. of leaves/plant (12.13) was found in treatment $9(\mathrm{P} 60 \mathrm{~kg} / \mathrm{ha}+$ zinc $25 \mathrm{~kg} / \mathrm{ha}+\mathrm{Fe}$ $25 \mathrm{~kg} / \mathrm{ha}$ ). However, treatment 3, 4 and 5 was found to be at par with this. The maximum number of leaves per plant was due to availability of adequate phosphorus at higher levels of application which encouraged leaf expansion and growth. Similar observations were also recorded by Gemechu (2011) and Araei and Mojaddam (2014) (Table 1).

Table.1 Effect of phosphorous, zinc and iron levels on growth attributes of maize

\begin{tabular}{|c|c|c|c|c|c|}
\hline \multirow[t]{2}{*}{ Treatment Details } & \multicolumn{3}{|c|}{ At 100 DAS } & \multicolumn{2}{|l|}{ 80-100 DAS } \\
\hline & $\begin{array}{l}\text { Plant } \\
\text { height } \\
(\mathrm{cm})\end{array}$ & $\begin{array}{l}\text { No. of } \\
\text { Leaves } \\
\text { /plant }\end{array}$ & $\begin{array}{l}\text { Plant } \\
\text { dry } \\
\text { weight } \\
\text { (g) }\end{array}$ & $\begin{array}{l}\text { CGR } \\
\left(\mathrm{g} / \mathrm{m}^{2} / \text { day }\right)\end{array}$ & $\begin{array}{l}\text { RGR } \\
\text { (g/g/day) }\end{array}$ \\
\hline $\begin{array}{l}\text { 1. Control (120:60:60 soil application of } \\
\text { NPK) }\end{array}$ & 185.44 & 11.33 & 154.96 & 12.05 & 0.010 \\
\hline 2. P $45 \mathrm{~kg} / \mathrm{ha}+$ Zinc $20 \mathrm{~kg} / \mathrm{ha}+$ Iron $20 \mathrm{~kg} / \mathrm{ha}$ & 186.22 & 11.66 & 163.56 & 14.07 & 0.011 \\
\hline 3. P $45 \mathrm{~kg} / \mathrm{ha}+$ Zinc $20 \mathrm{~kg} / \mathrm{ha}+\mathrm{Fe} 25 \mathrm{~kg} / \mathrm{ha}$ & 194.24 & 12.40 & 165.03 & 13.80 & 0.010 \\
\hline 4. $P 45 \mathrm{~kg} / \mathrm{ha}+$ Zinc $25 \mathrm{~kg} / \mathrm{ha}+\mathrm{Fe} 20 \mathrm{~kg} / \mathrm{ha}$ & 194.66 & 11.76 & 166.10 & 12.25 & 0.009 \\
\hline 5. P $45 \mathrm{~kg} / \mathrm{ha}+$ zinc $25 \mathrm{~kg} / \mathrm{ha}+\mathrm{Fe} 25 \mathrm{~kg} / \mathrm{ha}$ & 184.46 & 12.46 & 161.36 & 13.71 & 0.011 \\
\hline 6. $P 60 \mathrm{~kg} / \mathrm{ha}+$ zinc $20 \mathrm{~kg} / \mathrm{ha}+\mathrm{Fe} 20 \mathrm{~kg} / \mathrm{ha}$ & 190.32 & 11.40 & 167.43 & 12.26 & 0.009 \\
\hline $7 . P 60 \mathrm{~kg} / \mathrm{ha}+$ zinc $20 \mathrm{~kg} / \mathrm{ha}+\mathrm{Fe} 25 \mathrm{~kg} / \mathrm{ha}$ & 196.72 & 11.36 & 169.90 & 12.93 & 0.009 \\
\hline $8 . P 60 \mathrm{~kg} / \mathrm{ha}+$ zinc $25 \mathrm{~kg} / \mathrm{ha}+$ Fe $20 \mathrm{~kg} / \mathrm{ha}$ & 190.50 & 11.66 & 174.93 & 14.56 & 0.010 \\
\hline 9. P $60 \mathrm{~kg} / \mathrm{ha}+$ zinc $25 \mathrm{~kg} / \mathrm{ha}+\mathrm{Fe} 25 \mathrm{~kg} / \mathrm{ha}$ & 199.03 & 12.73 & 176.23 & 12.25 & 0.009 \\
\hline F test & S & $\mathrm{S}$ & S & NS & NS \\
\hline $\mathbf{S E}(\mathbf{m})$ & 3.36 & 0.35 & 1.75 & 1.78 & 0.001 \\
\hline $\mathrm{CD}(\mathrm{P}=\mathbf{0 . 0 5})$ & 9.86 & 1.05 & 5.30 & - & - \\
\hline
\end{tabular}


Table.2 Effect of phosphorous, zinc and iron levels on yield attributes and yield of maize

\begin{tabular}{|c|c|c|c|c|c|c|c|c|}
\hline Treatments & $\begin{array}{c}\text { Number } \\
\text { of } \\
\text { Cobs/PI } \\
\text { ant }\end{array}$ & $\begin{array}{c}\text { Number } \\
\text { of } \\
\text { Rows/ } \\
\text { Cob }\end{array}$ & $\begin{array}{c}\text { Number } \\
\text { of } \\
\text { Grains/ } \\
\text { Cob }\end{array}$ & $\begin{array}{c}\text { Number } \\
\text { of } \\
\text { Grains/ } \\
\text { Row }\end{array}$ & $\begin{array}{c}\text { Test } \\
\text { Weight } \\
\text { (g) }\end{array}$ & $\begin{array}{l}\text { Grain } \\
\text { Yield } \\
\text { (t/ha) }\end{array}$ & $\begin{array}{l}\text { Stover } \\
\text { Yield } \\
\text { (t/ha) }\end{array}$ & $\begin{array}{c}\text { Harvest } \\
\text { Index } \\
(\%)\end{array}$ \\
\hline $\begin{array}{l}\text { 1. Control (120:60:60 soil } \\
\text { application of NPK) }\end{array}$ & 1.06 & 12.22 & 185.87 & 15.20 & 254.33 & 1.97 & 4.23 & 31.73 \\
\hline $\begin{array}{l}\text { 2. P } 45 \mathrm{~kg} / \mathrm{ha}+\text { Zinc } 20 \\
\mathrm{~kg} / \mathrm{ha}+\text { Iron } 20 \mathrm{~kg} / \mathrm{ha}\end{array}$ & 1.20 & 13.99 & 248.34 & 17.73 & 268.66 & 2.34 & 4.63 & 33.62 \\
\hline $\begin{array}{l}\text { 3. P } 45 \mathrm{~kg} / \mathrm{ha}+\text { Zinc } 20 \\
\mathrm{~kg} / \mathrm{ha}+\mathrm{Fe} 25 \mathrm{~kg} / \mathrm{ha}\end{array}$ & 1.26 & 14.32 & 262.50 & 18.33 & 278.00 & 2.42 & 4.71 & 33.97 \\
\hline $\begin{array}{l}\text { 4. P } 45 \mathrm{~kg} / \mathrm{ha}+\text { Zinc } 25 \\
\mathrm{~kg} / \mathrm{ha}+\mathrm{Fe} 20 \mathrm{~kg} / \mathrm{ha}\end{array}$ & 1.40 & 14.44 & 280.33 & 19.40 & 281.00 & 2.47 & 4.86 & 33.83 \\
\hline $\begin{array}{l}\text { 5. P } 45 \mathrm{~kg} / \mathrm{ha}+\text { zinc } 25 \\
\mathrm{~kg} / \mathrm{ha}+\mathrm{Fe} 25 \mathrm{~kg} / \mathrm{ha}\end{array}$ & 1.13 & 12.66 & 206.87 & 16.33 & 262.66 & 2.29 & 4.53 & 33.64 \\
\hline $\begin{array}{l}\text { 6. P } 60 \mathrm{~kg} / \mathrm{ha}+\text { zinc } 20 \\
\mathrm{~kg} / \mathrm{ha}+\mathrm{Fe} 20 \mathrm{~kg} / \mathrm{ha}\end{array}$ & 1.46 & 15.11 & 326.53 & 21.60 & 288.66 & 2.51 & 4.89 & 33.93 \\
\hline $\begin{array}{l}\text { 7. P } 60 \mathrm{~kg} / \mathrm{ha}+\text { zinc } 20 \\
\mathrm{~kg} / \mathrm{ha}+\mathrm{Fe} 25 \mathrm{~kg} / \mathrm{ha}\end{array}$ & 1.66 & 15.33 & 354.01 & 23.06 & 300.33 & 2.59 & 5.04 & 33.93 \\
\hline $\begin{array}{l}\text { 8. P } 60 \mathrm{~kg} / \mathrm{ha}+\text { zinc } 25 \\
\mathrm{~kg} / \mathrm{ha}+\mathrm{Fe} 20 \mathrm{~kg} / \mathrm{ha}\end{array}$ & 1.73 & 16.66 & 386.57 & 23.20 & 310.33 & 2.65 & 5.18 & 34.03 \\
\hline $\begin{array}{l}\text { 9. P } 60 \mathrm{~kg} / \mathrm{ha}+\text { zinc } 25 \\
\mathrm{~kg} / \mathrm{ha}+\mathrm{Fe} 25 \mathrm{~kg} / \mathrm{ha}\end{array}$ & 1.86 & 17.10 & 412.76 & 24.13 & 318.00 & 2.77 & 5.23 & 34.66 \\
\hline F test & $\mathrm{S}$ & $\mathrm{S}$ & $\mathrm{S}$ & $\mathrm{S}$ & $\mathrm{S}$ & $\mathrm{S}$ & $\mathrm{S}$ & NS \\
\hline $\mathrm{SE}(\mathrm{m})$ & 0.09 & 0.41 & 11.68 & 0.31 & 4.78 & 0.02 & 0.17 & 0.76 \\
\hline $\mathrm{CD}(\mathrm{P}=0.05)$ & 0.28 & 1.26 & 34.34 & 0.95 & 14.47 & 0.07 & 0.53 & - \\
\hline
\end{tabular}

Table.3 Effect of phosphorous, zinc and iron levels on economics of maize

\begin{tabular}{|l|c|c|c|c|}
\hline \multicolumn{1}{|c|}{ Treatment No. } & $\begin{array}{c}\text { Cost of } \\
\text { cultivation(INR/ha) }\end{array}$ & $\begin{array}{c}\text { Gross } \\
\text { return(INR/ha) }\end{array}$ & $\begin{array}{c}\text { Net } \\
\text { return(INR/ha) }\end{array}$ & B:CRatio \\
\hline 1. Control (120:60:60 soil application of NPK) & 46323.00 & 63330.00 & 17007.00 & 1.37 \\
\hline 2. P 45 kg/ha + Zinc 20 kg/ha + Iron 20 kg/ha & 47616.75 & 74830.00 & 27213.25 & 1.57 \\
\hline 3. P 45 kg/ha + Zinc 20 kg/ha + Fe 25 kg/ha & 47916.75 & 77310.00 & 29393.25 & 1.61 \\
\hline 4. P 45 kg/ha + Zinc 25 kg/ha + Fe 20 kg/ha & 47991.75 & 78960.00 & 30968.25 & 1.65 \\
\hline 5. P 45 kg/ha + zinc 25 kg/ha + Fe 25 kg/ha & 48291.75 & 73230.00 & 24938.25 & 1.52 \\
\hline 6. P 60 kg/ha + zinc 20 kg/ha + Fe 20 kg/ha & 49023.00 & 80190.00 & 31167.00 & 1.64 \\
\hline 7. P 60 kg/ha + zinc 20 kg/ha + Fe 25 kg/ha & 49323.00 & 82740.00 & 33417.00 & 1.68 \\
\hline 8. P 60 kg/ha + zinc 25 kg/ha + Fe 20 kg/ha & 49398.00 & 84680.00 & 35282.00 & 1.71 \\
\hline 9. P 60 kg/ha + zinc 25 kg/ha + Fe 25 kg/ha & 49698.00 & 88330.00 & 38632.00 & 1.78 \\
\hline
\end{tabular}

At 100 DAS the significant and maximum plant dry weight $(176.23 \mathrm{~g})$ was found in treatment 9 (P $60 \mathrm{~kg} / \mathrm{ha}+$ zinc $25 \mathrm{~kg} / \mathrm{ha}+\mathrm{Fe}$ $25 \mathrm{~kg} / \mathrm{ha}$ ). However, treatment 8 was found to be at par with this. Application of phosphorus at $60 \mathrm{~kg} / \mathrm{ha}(\mathrm{P} 2)$ resulted in higher dry matter, which was comparable to $80 \mathrm{~kg} / \mathrm{ha}$ (P3) and significantly superior to $40 \mathrm{~kg} / \mathrm{ha}$ (P1). It seems the reason is increase in leaf area, photosynthesis improvement resulting in higher dry matter. Araei and Mojaddam (2014) also recorded the highest dry weight 
and leaf area of maize by applying $60 \mathrm{~kg} \mathrm{P}$ ha1 over 0 and $90 \mathrm{~kg} /$ ha P2O5Reddy et al., 2018. For GGR and RGR, there is no significant difference among the treatment combinations.

\section{Post-harvest observation}

The significant variation in No. of cob/plant was due to different treatment combination the maximum No. of cob/plant 1.86/plant was found in treatment $9(\mathrm{P} 60 \mathrm{~kg} / \mathrm{ha}+$ zinc 25 $\mathrm{kg} / \mathrm{ha}+\mathrm{Fe} 25 \mathrm{~kg} / \mathrm{ha})$. However, treatment 7 and 8 was found to be at par with the treatment.

The significant and maximum Cob length $(20.14 \mathrm{~cm})$ was found in treatment 9 (P 60 $\mathrm{kg} / \mathrm{ha}+$ zinc $25 \mathrm{~kg} / \mathrm{ha}+\mathrm{Fe} 25 \mathrm{~kg} / \mathrm{ha}$ ). Which was found to be most significant.

The significant and maximum No. of row/cob (17.10) was found in treatment $9(\mathrm{P} 60 \mathrm{~kg} / \mathrm{ha}$ + zinc $25 \mathrm{~kg} / \mathrm{ha}+\mathrm{Fe} 25 \mathrm{~kg} / \mathrm{ha}$ ). However, treatment 8 was found to be at par with this.

The significant and maximum No. of grain/row (24.13) was found in treatment $9(\mathrm{P}$ $60 \mathrm{~kg} / \mathrm{ha}+$ zinc $25 \mathrm{~kg} / \mathrm{ha}+\mathrm{Fe} 25 \mathrm{~kg} / \mathrm{ha})$. However, treatment 8 was found to be at par with this. The significant and maximum No. of grain/cob (24.13) was found in treatment 9 $(\mathrm{P} 60 \mathrm{~kg} / \mathrm{ha}+$ zinc $25 \mathrm{~kg} / \mathrm{ha}+\mathrm{Fe} 25 \mathrm{~kg} / \mathrm{ha})$ however treatment 8 was found at par with this.

Application of phosphorus at $60 \mathrm{~kg} / \mathrm{ha}(\mathrm{P} 2)$ resulted in higher dry matter, No. of grain/cob, Cob length, and No. of cob/plant which was comparable to $80 \mathrm{~kg} / \mathrm{ha}(\mathrm{P} 3)$ and significantly superior to $40 \mathrm{~kg} / \mathrm{ha}$ (P1).It seems the reason is increase in leaf area, photosynthesis improvement resulting in higher dry matter. Araei and Mojaddam (2014) also recorded the highest dry weight and leaf area of maize by applying $60 \mathrm{~kg} \mathrm{P}$ ha1 over 0 and $90 \mathrm{~kg} /$ ha P2O5 Reddy et al., 2018

The significant and maximum Test weight (318.0g) was found in treatment number 9 (P $60 \mathrm{~kg} / \mathrm{ha}+$ zinc $25 \mathrm{~kg} / \mathrm{ha}+\mathrm{Fe} 25 \mathrm{~kg} / \mathrm{ha})$. However, treatment 8 was found to be at par with this. The significant and maximum Grain yield $2.77 \mathrm{t} /$ ha was found in treatment number 9 (P 60 kg/ha + zinc 25 kg/ha + Fe 25 kg/ha). However, treatment 8 was found to be at par with this.

The significant and maximum straw yield $5.22 \mathrm{t} /$ ha was found in treatment number $9(\mathrm{P}$ $60 \mathrm{~kg} / \mathrm{ha}+$ zinc $25 \mathrm{~kg} / \mathrm{ha}+\mathrm{Fe} 25 \mathrm{~kg} / \mathrm{ha})$. However, treatment 8 was found to be at par with this. The significant and maximum Harvest index $34.66 \%$ was found in treatment 9 which was most significant among all treatment (Table 2).

Maize supplied with $60 \mathrm{~kg} / \mathrm{ha} \quad \mathrm{P}_{2} \mathrm{O}_{5}$ (P2) resulted in higher grain yield, which was however statistically on par with $45 \mathrm{~kg} / \mathrm{ha}$ $\mathrm{P}_{2} \mathrm{O}_{5}$ (P3). Significantly lowest grain yield was obtained with $40 \mathrm{~kg} / \mathrm{ha} \mathrm{P}_{2} \mathrm{O}_{5}(\mathrm{P} 1)$ in the first year. Similar trend was observed during the second year but all the three phosphorus levels recorded statistically on par values of grain yield.

Stover yield of maize increased significantly up to $60 \mathrm{~kg} / \mathrm{ha} \mathrm{P}_{2} \mathrm{O}_{5}$. Further increase in $\mathrm{P}$ from 60 to $80 \mathrm{~kg} /$ ha $\mathrm{P}_{2} \mathrm{O}_{5}$, decreased the stover yield. Higher straw yield at medium phosphorus level could be attributed to adequate and balanced nutrient supply over higher and lower levels. Similar results were obtained by Araei and Mojaddam (2014) and Nsanzabaganwa et al., 2014.

\section{Economics}

The cost of cultivation is given in Table 3. and the variable Cost of cultivation is given in 
table 3. However, the total cost of cultivation varies between Rs. 46323 to Rs. 49698.

The maximum gross return Rs. 88330/ha was found in Treatment 9 (P $60 \mathrm{~kg} / \mathrm{ha}+$ zinc 25 $\mathrm{kg} / \mathrm{ha}+\mathrm{Fe} 25 \mathrm{~kg} / \mathrm{ha}$ ) However the minimum Gross return Rs. 63330/ha was found in control plot. The maximum net return Rs. 38632/ha was found in Treatment 9 (P 60 $\mathrm{kg} / \mathrm{ha}+$ zinc $25 \mathrm{~kg} / \mathrm{ha}+\mathrm{Fe} 25 \mathrm{~kg} / \mathrm{ha}$ ). The $\mathrm{B}: \mathrm{C}$ ratio varies between 1.37 and 1.78 and the maximum $\mathrm{B}: \mathrm{C} 11.78$ was found in Treatment P 60 kg/ha + zinc $25 \mathrm{~kg} / \mathrm{ha}+$ Fe 25 $\mathrm{kg} / \mathrm{ha})$.

From the one year experiment it can be concluded that treatment 9 (P $60 \mathrm{~kg} / \mathrm{ha}+$ zinc $25 \mathrm{~kg} / \mathrm{ha}+\mathrm{Fe} 25 \mathrm{~kg} / \mathrm{ha}$ ) gave maximum Plant height, No. of leaves, Plant dry weight, No. of cob/plant, Cob length, No. of row/cob, No. of grain / row, No. o grain / cob, Test weight, Grain yield, Stover yield and Harvest index.

\section{References}

Abera, T., Feyisa, D and Friesen, D. K. 2009. Effects of Crop Rotation and N-P Fertilizer Rate on Grain Yield and Related Characteristics of Maize and Soil Fertility at Bako, Western Oromia, Ethiopia. East African Journal of Sciences. 3(1): 70-79.

Ahmed, M. K. Anonymous, Agricultural Statistics at a Glance. 2010 Directorate of Economics and Statistics, New Delhi. Amin, M., Razzaq, A., Ullah, R. and Ramzan, M. 1989. Effect of planting methods, seed density and Nitrogen Phosphorus (NP) fertilizer levels on sweet corn (Zea mays L.). Journal of Research (Science) 17(2): 83-89.

Asghar, A., Azhar, G. M., Mummad, W., Ayub, M., Asif, I. and Atta, U. M., 2011, Influence of Integrated nutrients growth, yield and quality of maize. American J. pl. sci., 1(2): 63-69
Anonymous, Agricultural Statistics at a Glance. 2014 Directorate of Economics and Statistics, New Delhi. Ahmed, M. A. and Ahmed, M. K. A., 2005, Growth and productivity of wheat plants as affected by complete foliar fertilizer compound under water stress in newly cultivated sandyland. Arab Universities J. Agric. Sci., 13(2): 269-284.

Ahmed, M. A. and Ahmed, M. K. A., 2015, Growth and productivity of wheat plants as affected by complete foliar fertilizer compound under water stress in newly cultivated sandyland. Arab Universities J. Agric. Sci., 13(2): 269-284.

Brar, N.S., R.S., Singh, T. and Yadav, S.K. 2016. Effect of irrigation and fertility levels on nitrogen and phosphorus uptake in winter maize under shallow water table conditions in Haryana. Indian Journal of Soil Conservation29(2) :135- 136.

Bubarai, A.M. Tahir and Solomon, R.I. 2., 2017, The Micronutrients Boron Its Influence on Growth and Development of Plants and Factors Affecting Availabilty. IOSR Journal of Agriculture and Veterinary Science (IOSR-JAVS) e-ISSN: 2319-2380, pISSN: 2319-2372. Volume 10, Issue 12 Ver. I (December 2017), PP 10-13

Barbara M Humtsoe, Joy Dawson and PraveenaRajana 2018. Effect of nitrogen, boron and zinc as basal and foliar application on growth and yield of maize (Zea mays L.) Journal of Pharmacognosy and Phytochemistry; 7(6): 01-04.

Chakraborti, M., B.M. Prasanna, F. Hossain, and A.M. Singh. 2011. Evaluation of single cross quality protein maize (QPM) hybrids for kernel iron and zinc concentrations. Indian J. Genet. Plant Breed. 71:312-319

Dassoni, F., Z. Abebe, F. Ricceri, A. Morrone, C. Albertin, and B. Naafs. 
2014. High frequency of symptomatic zinc deficiency in infants in northern Ethiopia. Dermatol. Res. Pract. 2014:719701. doi:10.1155/2014/719701

Ehsanullah,' A. Tariq., MA Randhawa, S.A. Anjum, M. Nadeem and M. Naeem. 2015. Exploring the role of zinc in maize (Zea mays L.) through soil and foliar application. Universal Journal of Agricultural Research, 3(3): 69-75.

FarshidAref, 2011, Influence of zinc and boron nutrition on copper, manganese and iron Concentration in the maize leaf. Australian J. basic and applied sci., 5(7): 52

Fageria, N.K., and L.F. Stone. 2012. Micronutrient deficiency problems in South America. In: B.J. Alloway, editor, Micronutrient deficiencies in global crop production. Springer, Dordrecht, the Netherlands. p. 245-266. doi:10.1007/978-1-4020-6860-7_10

Gomez, K.A. and Gomez, A.A., 1984. Statistical Procedures for Agricultural Research, edn 2, An International Rice Research Institute Book. Wiley-InterScience Publication, John Wiley \& Sons, New York.

Ghandilyan, A., D. Vreugdenhil, and M.G.M. Aarts. 2006. Progress in the genetic understanding of plant iron and zinc nutrition. Physiol. Plant. 126:407-417. doi:10.1111/j.1399- 3054.2006.00646.x

Gibson, R.S. 2007. The role of diet- and hostrelated factors in nutrient bioavailability and thus in nutrient-based dietary requirement estimates. Food Nutr. Bull. 28:S77-S100. doi:10.1177/1564826507 0281S108

Gemechu, G. A. 2011. Influence of nitrogen and phosphorus fertilizers on seed yield and quality of maize (Zea mays L.) at Bedele, South-Western Ethiopia. M. Sc thesis submitted to the Department of Plant Sciences, School of Graduate Studies, Haramaya University, Ethiopia
Gibson, R.S. 2012. Zinc deficiency and human health: Etiology, health consequences, and future solutions. Plant Soil361:291- 299. doi:10.1007/s11104-012-1209-4

García-Bañuelos, M.L., J.P. Sida-Arreola, and E. Sánchez. 2014. Biofortification: Promising approach to increasing the content of iron and zinc in staple food crops. J. Elem. 19:865-888. doi:10.5601/jelem.2014.19.3.708

Goudia, B.D., and C.T. Hash. 2015. Breeding for high grain $\mathrm{Fe}$ and $\mathrm{Zn}$ levels in cereals. Int. J. Innovation Appl. Stud. 12:342- 354

Garg, M., N. Sharma, S. Sharma, P. Kapoor, A. Kumar, V. Chunduri, and P. Arora. 2018. Biofortified crops generated by breeding, agronomy and transgenic approaches are improving lives of millions of people around the world. Front. Nutr. 5:12. doi:10.3389/fnut.2018.00012

Hythum, M., Nasser, Kh B. EI- Gizawy., 2012, Importance of micronutrients and its application methods for improving maize (Zea mays L.) yield grown in clayey soil. American -Eurasian $J$. Agric \& Environ. Sci., 12(7): 954-959.

Hamzeh, M., Rawashdeh. and Florin, S., 2015, Foliar application with iron as a vital factor of wheat crop growth, yield quantity and quality. International Journal of Agriculture Policy and Research vol 3(9), pp. 368-376.

Kanwal, S., Ranjha, A.M. and Ahmad R., 2010, zinc partitioning in maize grain after soil fertilization with zinc sulfate. International Journal of Agriculture and Biology. 09-462/HUT/2010/12-2299-302.

Kumar Ravi, R. 2014. Growth effect of phosphorus and rhizobium inoculation in some cereal crops. International Journal Current Sciences. 1-6.

Maqsood, M., A.M. Abid, A. Iqbal and M.I. 
Hussain. 2001. Effect of various rates of nitrogen and phosphorus on growth and yield of maize. Pak. J. Biol. Sci. 1: 1920.

Mehta, Y.K., Shaktawat, M.S. and Singh, S.M. 2005. Influence of sulphur, phosphorus and farmyard manure on yield attributes and yield of maize (Zea mays L.) in southern Rajasthan conditions. Indian J. Agron.,50: 203205.

Manasa, L.P. and Devaranavadagi, 2015, effect of foliar application of micronutrients on growth, yield and nutrient uptake of maize Karnataka $J$. Agric. Sci., 28(4): (474-476).

Nadeem, M., Tariq, A., Anjum, S.A., Randhawa, M. A., Ullah, E., Naeem, M., Qamar, R., Ashraf, U. and 2014,influence of Zinc Nutrition on Growth and Yield Behaviour of Maize (Zea mays L.) Hbrids. American J. pl. Sci., 5: 2646-2654.

Nsanzabaganwa, E., Das, T. K and Rana, D. S. 2014. Nitrogen and phosphorus effects on the growth, phenology, heat and nutrients accumulation and yield of winter maize (Zea mays) in Western Indo-Gangetic Plains. Indian Journal of Agricultural Sciences. 84 (5): 661-664.

Ortiz-Monasterio, J.I., N. Palacios-Rojas, E. Meng, K. Pixley, R. Trethowan, and R.J. Peña. 2007. Enhancing the mineral and vitamin content of wheat and maize through plant breeding. J. Cereal Sci. 46:293-307.

doi: 10.1016/j.jcs.2007.06.005

Parasuraman, P., R. Prakash and B. Chandrasekaran 2008. Response of hybrid maize (Zea mays L.) to soil and foliar application of nutrients. Madras Agric. J, 95(1-6): 200-202.

Potarzyckd, J. and W. Grzebisz 2009. Effect of zinc foliar application on grain yield of maize and its yielding components. Plant Soil Environ., 55(12): 519-527.
Paramasivan, M., K.R. Kumaresan, P. Malarvizhi, S. Mahimairaja and K. Velayudham 2010. Effect of different levels of NPK and $\mathrm{Zn}$ on yield and nutrient uptake of hybrid maize (COHM 5) (Zea mays L.) in Mudhukkur (Mdk) series of soils of Tamilnadu. Asian $J$. Soil Set, 5(2): 236-240.

Panhwar Q.A., Radziah O., Khanif, Y.M., Naher, U.A., 2011, application of boron and zinc in the tropical soils and its effect on maize (Zea mays L.) growth and soil microbial environment. Australian Journal of Crop Science AJCS5(12):1649- 1654.

Pasricha, S.-R., H. Drakesmith, J. Black, D. Hipgrave, and B.-A. Biggs. 2013. Control of iron deficiency anemia in low- and middle-income countries. Blood121:2607-2617. doi:10.1182/ blood-2012-09-453522

Rashid, A. and K.S. Memon. 2001.Soil and fertilizer phosphorus. Soil Sci. B. Elenaand R. Bantel (Eds). National Book Foundation, Islamabad, Pakistan. pp. 300-302

Ravikiran, S and A.S. Halepyati 2013. Yield and yield components, quality parameters, uptake of nutrients and economics of $\mathrm{Bt}$ cotton (Gossypium hirsutum L.) as influenced by macro and soluble micronutrients under irrigation. Crop Res., 45(1,2 \& 3): 253-258.

Randhawa, M. A., Tariq, A., Anjum, S.A., Ullah, E., Naeem, M., Qamar, R., Ashraf, U. and Nadeem, M., 2014, influence of Zinc Nutrition on Growth and Yield Behaviour of Maize (Zea mays L.) Hbrids. American J. pl. Sci., 5: 2646-2654.

Saeed, I. M., Abbasi, R and Kazim, M. 2001. Response of maize (Zea mays) to nitrogen and phosphorus fertilization under agro-climatic condition of Rawalokol, Jammu and Kaslim and Kashmir. Pakistan Journal of Biological 
Sciences. 4: 949-952

Soomro, Z. H., Baloch, P. A. and Gandhai, A. W., 2011; Comparative effect of foliar and soil applied boron on growth and fodder yield of maize. Pakistan J. Agric. Sci., 27(1): 18-26.

Swaminathan, M.S. 2012. Combating hunger. Science338:1009. doi:10.1126/science.1231305

Salih, H.O. 2013. Effect of foliar fertilization of $\mathrm{Fe}, \mathrm{B}$ and $\mathrm{Zn}$ on nutrient concentration and seed protein of cowpea "Vigna unguiculata". IOSR Journal of Agriculture and Veterinary Science, 6(3): 42-46. Hindawi publishing corporation. International scholarly research notice

Tariq, A., Anjum, S.A., Randhawa, M. A., Ullah, E., Naeem, M., Qamar, R., Ashraf, U. and Nadeem, M., 2014, influence of Zinc Nutrition on Growth and Yield Behaviour of Maize (Zea mays L.) Hbrids. American J. pl. Sci., 5: 2646-2654.

Thakur, D.R., Singh, K.K. and Thakur, R.C. 2015. Studies on weed and fertilizer management in rainfed maize (Zea mays L.) under the mid-hill conditions of H.P. Himachal Journal of Agriculture Research, 18(1\&2): 1-4

Tako, E., H. Bar, and R. Glahn. 2016. The combined application of the Caco- 2 cell bioassay coupled with in vivo (Gallus gallus) feeding trial represents an effective approach to predicting $\mathrm{Fe}$ bioavailability in humans. Nutrients, 8: 732. doi: $10.3390 /$ nu8110732

Vasconcelos, M.W., W. Gruissem, and N.K. Bhullar. 2017. Iron biofortification in the 21st century: Setting realistic targets, overcoming obstacles, and new strategies for healthy nutrition. Curr. Opin. Biotechnol. 44:8-15. doi:10.1016/j.copbio.2016.10.001

Welch, R.M., and R.D. Graham. 2004. Breeding for micronutrients in staple food crops from a human nutrition perspective. J. Exp. Bot. 55:353-364. Welch, R.M., and R.D. Graham. 2005. Agriculture: The real nexus for enhancing bioavailable micronutrients in food crops. J. Trace Elem. Med. Biol.18:299- 307. doi:10.1016/j. jtemb.2005.03.001

\section{How to cite this article:}

Manoj Pal Thakur, Joy Dawson and Tarun Thakur. 2020. Effect of Phosphorus, Zinc and Iron Levels on Growth and Yield of Kharif Maize (Zea mays L.). Int.J.Curr.Microbiol.App.Sci. 9(12): 2312-2323. doi: https://doi.org/10.20546/ijcmas.2020.912.274 